\title{
Tipe Kepribadian Big Five, Sense of Humor dan Subjective Well-Being pada Mahasiswa UIN Suska Riau
}

\author{
Deddi Zulfadri, Raudatussalamah
}

Fakultas Psikologi Universitas Islam Negeri Sultan Syarif Kasim Riau email: deddizulfadri@yahoo.com, raudatussalamah@uin-suska.ac.id

\begin{tabular}{l} 
Artikel INFO \\
\hline Diterima:24 Juli 2019 \\
Direvisi :26 juli 2019 \\
Disetujui: 27 Juli 2019 \\
\hline DOI: \\
http://dx.doi.org/10.24014/ \\
jp.v14i2.7416
\end{tabular}

Mahasiswa dalam proses pengembangan ilmu pengetahuan dan teknologi diperguruan tinggi dihadapkan dengan banyaknya tuntutan. Tuntutan ini mengakibatkan tekanan yang memunculkan masalah-masalah psikologis. Evaluasi mahasiswa terhadap pengalaman masalah-masalah yang terjadi disebut dengan subjective well-being. Banyak faktor yang mempengaruhi subjective well-being, diantaranya tipe kepribadian big five dan sense of humor. Penelitian ini bertujuan untuk mengetahui hubungan antara tipe kepribadian big five dan sense of humor dengan subjective well-being mahasiswa UIN Suska Riau. Jumlah subjek dalam penelitian ini sebanyak 151 orang laki laki dan 242 orang perempuan. Analisa data yang digunakan dalam penelitian ini adalah teknik analisis regresi ganda. Hasil analisa menunjukkan hubungan yang signifikan antara tipe kepribadian big five dan sense of humor dengan subjective well-being. Sumbangan efektif tipe kepribadian big five dan sense of humor terhadap subjective well being sebesar $10,6 \%$. Hasil uji hipotesis minor diperoleh dua koefisien regresi yang signifikan hubungan terhadap subjective wellbeing yaitu tipe kepribadian conscientiousness dan sense of humor .

Kata Kunci: Tipe Kepribadian Big Five, Sense of Humor, Subjective Well-Being

\section{The Big Five Personality, Sense of Humor and Subjective Well-Being In Students of UIN Suska Riau}

\begin{abstract}
Students are facing many demands in their academic process. These demands lead to psychological pressure which may raises further psychological problems. Student evaluation of the experience of problems that occur is called subjective well-being. Many factors affect subjective well-being, including personality types and sense of humor. This study aims to determine the relationship between big five personality types and a sense of humor with subjective well-being of students at Suska Riau UIN. The number of participants in this study was 151 male and 242 female. Analysis of the data used in this study was multiple regression analysis. The results show a significant relationship between big five personality and a sense of humor with subjective well- Effective contribution of big five personality types and sense of humor towards subjective well being is $10.6 \%$. The results of the minor hypothesis test obtained two significant regression coefficients on subjective well-being, namely conscientiousness personality type and sense of humor
\end{abstract}

Keywords: Big Five Personality, Sense of Humor, Subjective Well-Being

\section{Pendahuluan}

Tantangan masa depan dapat disikapi dengan menciptakan pendidikan yang sanggup melengkapi masyarakatnya dengan informasi dan pengetahuan yang luas serta mendalam guna untuk kemajuan suatu bangsa. Tairas (2008) menyatakan perguruan tinggi merupakan center of excellence dan pusat pengembangan ilmu pengetahuan dan teknologi dituntut untuk memberikan kontribusi yang nyata dalam menghasilkan lulusan-Iulusan yang berkompeten dalam bidang ilmunya.

Mahasiswa merupakan komponen penting dari perguruan tinggi memiliki potensi yang besar untuk mentransformasikan pengetahuan dan kompetensinya bagi pengembangan ilmu pengetahuan dan teknologi untuk kepentingan pembangunan bangsa. Mahasiswa memiliki banyak tuntutan- 
tuntutan yang beraneka ragam yang harus dipenuhi, tuntutan ini akan mengakibatkan tekanan-tekanan yang memunculkan masalah-masalah psikologis yang berakibat negatif dalam kehidupan mahasiswa. Masalah-masalah psikologis yang dihadapi mahasiswa dapat diketahui melalui beberapa penelitian yang dilakukan oleh Heppner dkk, (dalam Lucas dan Berkel 2005) hasil penemuannya menemukan bahwa ada perbedaan karakteristik setelah mereka masuk perguruan tinggi akibat tekanan lingkungan baru yang dihadapi oleh mahasiswa.

Boyd, Holder, Hunt, Magorn dan Brunt (dalam Tairas, 2008) menyatakan bahwa banyak hal yang menjadi kekhawatiran dan tekanan yang dihadapi oleh seorang mahasiswa seperti, khawatir akan nilai, belajar secara efektif, mengatur waktu, tidur sedikit, menyiapkan ujian, tekanan akan waktu pengumpulan tugas terakhir dan tekanan karena terlalu banyak tugas. Perasaan negatif mahasiswa juga dapat dijumpai pada lingkungan perguruan tinggi, baik hubungan dengan rekan mahasiswa dan juga hubungan dengan staf akademisi maupun dosen.

Hubungan yang kurang harmonis antara mahasiswa dan dosen ditunjukkan oleh adanya polemik dugaan penganiayaan yang dilakukan oleh seorang dosen terhadap mahasiswanya disalah satu fakultas di UIN Suska Riau. Hubungan tidak harmonis pun di tunjukkan oleh mahasiswa dan pengurus organisasi kepemudaan. Permasalahan permasalahan yang dihadapi oleh mahasiswa ini berpengaruh kepada kondisi psikis mahasiswa. Mahasiswa harus mampu dan yakin dalam menghadapi segala masalah. Apabila mahasiswa memiliki keyakinan maka masalah yang dihadapi di anggap sebagai tantangan bukan beban dan nantinya akan berdampak pada subjective well-being mahasiswa. Subjective well-being (SWB) adalah suatu bentuk evaluasi mengenai kehidupan individu itu sendiri. Diener (dalam Erlangga, 2002) menyatakan bentuk evaluasi dapat dilakukan dengan dua cara yaitu: penilaian kognitif seperti kepuasan hidup, dan respon emosional terhadap suatu kejadian, seperti merasakan emosi yang positif.
Mahasiswa harus berada pada lingkungan yang menyenangkan dan membangun hubungan yang baik antar sesama rekan mahasiswa maupun hubungan baik dengan dosen untuk dapat merasakan emosi positif. Mahasiswa yang berada pada lingkungan yang menyenangkan atau keadaan yang penuh dengan humor, merupakan salah satu cara untuk meraih SWB. Sense of humor yang dimiliki dapat membuat mahasiswa lebih santai dan lebih memaknai positif terhadap permasalahan yang terjadi dalam kehidupannya. Individu yang memiliki sense of humor cenderung dalam keadaan yang memiliki SWB. Semakin tinggi sense of humoryang dimiliki seseorang, maka semakin tinggi pula SWB yang dimiliki (Humaira dan Qodariah, 2017).

Setiap orang cenderung berbeda dalam mengungkapkan perasaan dan emosinya karena kepribadian yang dibawanya. Karakteristik kepribadian setiap manusia berbeda-beda antara satu dengan yang lain. Tidak hanya sense of humor, kepribadian merupakan salah satu faktor yang mempengaruhi SWB. Karena kepribadian merupakan faktor yang paling kuat dan konsisten dari SWB (Diener, Suh, Lucas dan Smith, 1999). Kepribadian big five merupakan salah satu teori kepribadian yang dikembangkan dengan lima faktor yang mencerminkan kemampuan seseorang untuk berprilaku tertentu dengan lebih baik atau tidak (Costa dan McCrae, dalam Feist dan Feist, 2010). Dalam kepribadian big five terdapat lima dimensi kepribadian, yaitu Extraversion, Agreeableness, Conscientiousness, Neuroticism dan Openess to New Experience. DeNeve dan Cooper (Karim, 2018) dalam penelitian meta analisis menunjukkan bukti bahwa Exstraversion dan Neuroticism merupakan predictor big five yang paling kuat terhadap kesejahteraan. Sedangkan prediktor big five terkuat terhadap kepuasan hidup individu adalah neuroticism dan conscientiousness.

Berangkat dari fenomena-fenomena yang telah dipaparkan di atas tersebut, maka penulis tertarik untuk melakukan penelitian mengenai hubungan tipe kepribadian big 
five dan sense of humor dengan SWB pada mahasiswa UIN Suska Riau. Peneliti memiliki tiga hipotesis di dalam penelitian ini, yaitu bahwa: 1) secara bersama-sama terdapat hubungan antara tipe kepribadian big five dan sense of humor dengan SWB pada mahasiswa UIN Suska Riau, 2) terdapat hubungan antara tipe kepribadian big five dengan SWB pada mahasiswa UIN Suska Riau, dan 3) terdapat hubungan antara sense of humor dengan SWB pada mahasiswa UIN Suska Riau.

\section{Metode}

\section{Desain Penelitian}

Terdapat tiga variabel dalam penelitian ini, yaitu tipe kepribadian big five dan sense of humor sebagai variabel prediktor (variabel bebas) dan SWB sebagai variabel kriteria (variabel terikat).

Subjek

Partisipan dalam penelitian ini ialah mahasiswa aktif yang sedang menempuh Pendidikan S1 di UIN Suska Riau. Partisipan di ambil dengan menggunakan propotional random sampling, teknik ini digunakan karena populasi mempunyai anggota/unsur yang homogen secara proposional (Arikunto, 2010). Jumlah mahasiswa UIN Suska Riau pada tahun 2016/2017 sebanyak 24041 orang mahasiswa dari 8 fakultas. Penentuan partisipan dalam penelitian ini menggunakan rumus dari Slovin dengan tingkat kepercayaan sebesar 95\%, maka jumlah partisipan yang didapat adalah 393 pertisipan.

Pengukuran

Alat ukur yang digunakan untuk mengukur variabel SWB adalah Satisfaction With Life Scale (SWLS) dari Diener (1985) dan Positive Affect Negative Affect (PANAS) dari Watson, Clark, dan Tellegen (1988). Skala Multidimensional Sense Of Humor Scale (MSHS) dari Thorson, Powell, Schuller dan Hampes (1997) untuk mengukur variabel sense of humor. Serta skala IPIP Big-Five Factors Markers Factors Markersyang disusun oleh U.S National Intitute of Mental Health untuk mengukur variabel tipe kepribadian big five. Sebelum dilakukan pengambilan data, seluruh skala telah melalui proses adaptasi bahasa melalui translasi dari Bahasa Inggris ke Bahasa Indonesia, back-translate, serta uji keterbacaan.

Satisfaction With Life Scale merupakan alat ukur yang dikembangkan oleh Diener (1985) untuk mengukur evaluasi kognitif yaitu nilai kepuasan hidup, skala ini terdiri dari 5 aitem. Penulis menggunakan Positive Affect Negative Affect untuk mengukur tingkat terjadinya afek positif dan afek negatif dalam satu waktu, skala ini dikembangkan oleh Watson, Clark, dan Tellegen (1988) yang terdiri dari 10 afek positif dan 10 afek negatif. Untuk mendapatkan skor SWB penulis menjumlahkan true score yang diperoleh dari pengolahan data Satisfaction With Life Scale dan true score yang diperoleh dari pengolahan data Positive Affect Negative Affect.

Skala Sense of Humor yang disusun berdasar aspek sense of humor yang dikemukakan oleh Thorson, Powell, Schuller, dan Hampes (1997). Thorson, Powell, Schuller dan Hampes (1997) mengembangkan skala sense of humor melalui empat aspek, yaitu: humor production, coping with humor, humor appreciation, dan attitude toward humor yang disebut dengan Multidimensional Sense of Humor Scale (MSHS), skala ini terdiri dari 24 aitem.

Untuk mengukur tipe kepribadian Big Five, peneliti menggunakan modifikasi skala IPIP Big-Five Factors Markers Factors Markers yang disusun oleh U.S National Institute of Mental Health (ipip.ori.org). IPIP memiliki konsistensi internal baik dan sangat berkaitan dengan dimensi kepribadian (Zheng, Goldberg, Zheng, Zhoa, Tang, dan Liu, 2008). Menurut teori yang dikemukakan Costa dan McCrae, terdapat lima trait yang di ukur, yaitu Ekstraversi (Extraversion), Kesepakatan (Agreeableness), Kegigihan (Conscientiousness), Neurotis (Neuroticsm) dan Keterbukaan terhadap pengalaman (Openess to Experience), skala ini terdiri dari 50 aitem.

\section{Analisis Data}

Untuk menjawab hipotesis penelitian, peneliti melakukan analisis statistik menggu- 
nakan teknik uji regresi ganda dan uji regresi linear melalui SPSS 24.00 for windows. Nilai true score yang diperoleh kemudian dianalisis menggunakan analisis regresi berganda untuk uji hipotesis pertama, yaitu kontribusi variabel tipe kepribadian big five dan sense of humor dengan SWB. Sedangkan, analisis yang digunakan untuk mengetahui hubungan masing-masing variabel bebas dan variabel terikat menggunakan analisis regresi linear, uji regresi linear dilakukan secara terpisah dengan tujuan untuk menjawab hipotesis kedua dan hipotesis ketiga.

\section{Hasil}

Analisis pada 393 mahasiswa yang berpatisipasi dalam penelitian ini, ditemukan skor rata-rata SWB sebesar $\mathrm{M}=50.00$ (SD= 16.194). Dari hasil kategorisasi, sebanyak 49,1\% mahasiswa berada pada tingkat SWB pada kategori sedang. 23,9\% pada kategori tinggi dan $27 \%$ berada pada ketegori rendah. ini berarti kebanyakan mahasiswa yang menjadi subjek dalam penelitian ini memiliki SWB yang cukup baik.

Dengan kata lain, dalam kesehariannya mahasiswa sudah mampu mengatasi perasaan-perasaan negatif yang dirasakan dan merasakan kebahagian dalam hidupnya walaupun belum sepenuhnya sempurna. Kondisi itu yang dapat menyebabkan mahasiswa pada suatu waktu dan kondisi tertentu merasa puas dengan kehidupan yang dijalaninya, namun pada waktu dan kondisi yang lain merasa kurang puas dengan kehidupan yang dijalaninya.

Analisis variabel sense of humor, ditemukan skor rata-rata $\mathrm{M}=49.28(\mathrm{SD}=9.653$ ). Hasil kategorisasi didapat mahasiswa dalam penelitian ini memiliki tingkat kategori tinggi sebesar $14,8 \%$ dan $15 \%$ berada pada kategori rendah. Dengan demikian, dapat dikatakan bahwa mahasiswa sudah cukup baik dalam merasakan emosi positif walaupun dirinya dalam keadaan tertekan dan panik. Ini terjadi karna sense of humor yang dimiliki mahasiswa mampu untuk memodifikasi perspektif dalam situasi negatif tersebut, sehingga memperkenankan mahasiswa untuk menghindar dalam mengalami afek negatif dalam situasi tertentu. Dalam aspek kognisi, dengan tingkat kategori sense of humor yang cukup baik ini mahasiswa mampu mengapresiasi dan memproduksi humor melalui proses kognisi.

Subjek penelitian berdasarkan pembagian dimensi kepribadian big five 45 orang (11.5\%) adalah dimensi extraversion, 187 orang (47.6\%) adalah dimensi agreeableness, 96 orang (24.4\%) adalah dimensi conscientiousness, 30 orang (7.6\%) adalah dimensi neuroticsm, dan 35 orang $(8.9 \%)$ adalah dimensi Openness Uji Normalitas dan Linearitas

Uji normalitas merupakan pengujian yang dilakukan untuk melihat sebaran normal dari data yang ada. Salah satu bentuk uji normalitas yang digunakan dalam penelitian ini adalah teknik One Sample KolmogrovSmirnov, dengan signifikansi $p>0,05$ maka data dikatakan normal. Uji normalitas dalam penelitian ini dilakukan pada tiga variabel, yaitu variabel subjective well being, variabel tipe kepribadian big five, dan variabel sense of humor. Melalui bantuan Statistical Product and Service Solutions (SPSS) 24 for Windows. Berdasarkan hasil uji normalitas dengan program SPSS 24.0 for Windows diperoleh sebagai berikut:

Tabel 1 Uji Normalitas menggunakan Kolmogrov Smirnov

\begin{tabular}{cccc}
\hline Variabel & Kolmogrov-Smirnov & $\mathbf{P}$ & Keterangan \\
\hline Subjective well being & 0,041 & 0,108 & Normal \\
Extraversion & 0,044 & 0,063 & Normal \\
Agreeablesness & 0,041 & 0,120 & Normal \\
Concientiousness & 0,044 & 0,064 & Normal \\
Neuroticsm & 0,043 & 0,082 & Normal \\
Openess to experience & 0,043 & 0,077 & Normal \\
Tipe Kepribadian Big five & 0,042 & 0,093 & Normal \\
Sense of humor & 0,045 & 0,052 & Normal \\
\hline
\end{tabular}


Uji linearitas dilakukanuntuk mengetahui ada tidaknya hubungan linear antara variabel yaitu variabel tipe kepribadian big five dengan variabel subjective well being dan sense of Tabel 2 Uji Linearitas humor dengan variabel subjective well being dengan bantuan SPSS 24.0 for windows. Berdasarkan hasil analisis diperoleh hasil sebagai berikut:

\begin{tabular}{lccc}
\hline \multicolumn{1}{c}{ Variabel } & F & $\boldsymbol{P}$ & Keterangan \\
\hline Subjective well being dengan Tipe Kepribadian Big Five & 1715,66 & 0,001 & Linear \\
Subjective well being dengan Sense of Humor & 46,609 & 0,000 & Linear \\
Subjective well being dengan Extraversion & 1,323 & 0,302 & Tidak Linear \\
Subjective well being dengan Agreeableness & 0,429 & 0,531 & Tidak Linear \\
Subjective well being dengan Concientiousness & 152,820 & 0,001 & Linear \\
Subjective well being dengan Neurotiscm & 2,657 & 0,154 & Tidak Linear \\
Subjective well being dengan Openness & 0,117 & 0,765 & Tidak Linear \\
\hline
\end{tabular}

Uji linearitas yang digunakan dalam penelitian ini adalah uji $\mathrm{F}$, data akan dikatakan linear dengan ketentuan signifikansi lebih kecil dari 0,05 $(p<0,05)$. Berdasarkan tabel 2 didapatkan hasil pengujian linearitas pada variabel tipe kepribadian big five diketahui F sebesar 1715,66 dengan taraf signifikansi sebesar 0,001 ( $p<0,05)$ dengan begitu dikatakan linear. Sedangkan pada variabel sense of humor hasil pengujian linearitas diketahui bahwa $F$ sebesar 46,609 dengan taraf signifikansi sebesar 0,000 $(p<0,005)$ dengan begitu dikatakan linear.

Tabel 3 Uji Multikolinearitas

\begin{tabular}{ccc}
\hline \multirow{2}{*}{ Variabel } & \multicolumn{2}{c}{ Colinearity Statistic } \\
\cline { 2 - 3 } & Tolerance & VIF \\
\hline (Constant) & & 1,168 \\
\hline Tipe Kepribadian Big Five & 0,856 & 1,168 \\
Sense of Humor & 0,856 & 1,009 \\
Extraversion & 0,991 & 1,018 \\
Agreeableness & 0,983 & 1,013 \\
Concientiousness & 0,987 & 1,014 \\
Neuroticsm & 0,986 & 1,007 \\
Openness & 0,993 & \\
\hline
\end{tabular}

Uji Multikolinearitas

Uji multikolinearitas bertujuan untuk menguji apakah model regresi ditemukan adanya korelasi antar variabel bebas atau independent (Ghozali, 2006). Model regresi yang baik seharusnya tidak terjadi korelasi di antara variabel bebas. Dengan bantuan komputerisasi menggunakan aplikasi program
SPSS 24.0 for Windows, dapat mengetahui ada atau tidaknya multikolinearitas di dalam model regresi pada penelitian ini. Dengan melihat nilai VIF (Variance Inflation Faktor) dan nilai Tolerance, apabila nila VIF lebih kecil dari 10,00 dan nilai Tolerance lebih besar dari 0,1 maka tidak terjadi multikolinearitas. 
Tipe Kepribadian Big Five dan Sense of Humor dengan Subjective Well Being

Hasil uji hipotesis diperoleh nilai $\mathrm{F}=$ 23,104 dan $p=0,000$ (Sig. $<0,05$ ). Sehingga dapat disimpulkan bahwa hipotesis yang diajukan pada penelitian ini diterima. Dengan demikian terdapat hubungan antara tipe kepribadian big five dan sense of humor dengan SWB pada mahasiswa UIN Suska Riau. Sedangkan erolehan Adjusted $R$ square dari tipe kepribadian big five dan sense of humor dengan SWB sebesar 0,106 atau $10,6 \%$. Artinya proporsi varian SWB yang dijelaskan oleh tipe kepribadian big five dan sense of humor secara bersama sama adalah sebesar $10,6 \%$, sedangkan $89,4 \%$ sisanya dipengaruhi oleh variabel lain diluar penelitian ini.

Koefisien Regresi Tipe Kepribadian Big Five terhadap SWB

Pada tahapan ini, peneliti melihat pengaruh masing masing dimensi dari variabel bebas yakni tipe kepribadian big five terhadap SWB, dengan perolehan hasil sebagai berikut:

Tabel 4 Hasil Uji Hipotesis Koefisien Regresi

\begin{tabular}{|c|c|c|c|}
\hline \multirow{2}{*}{ Variabel } & \multicolumn{3}{|c|}{ Standardized Coefficients } \\
\hline & Beta & $\mathbf{t}$ & Sig. \\
\hline Extraversion & .051 & 1.048 & .295 \\
\hline Agreeablesness & .022 & .441 & .660 \\
\hline Concientiousness & .293 & 6.024 & .000 \\
\hline Neuroticsm & .042 & .863 & .389 \\
\hline Openness & -.004 & -.089 & .929 \\
\hline
\end{tabular}

Berdasarkan tabel 4 dapat diketahui bahwasanya ke lima dimensi dari tipe kepribadian big five terdapat satu dimensi yang secara signifikan mempengaruhi SWB, yaitu dimensi conscientiousness dimana nilai signifikansi dari dimensi conscientiousness $<0,05$, dan arah korelasi dimensi conscientiousness memiliki arah yang positif. Selanjutnya berdasarkan tabel 4 diketahui bahwa ke empat dimensi tipe kepribadian big five yakni, extraversion, agreeableness, neuroticsm dan openness secara signifikan tidak mempengaruhi SWB dimana nilai signifikansi $<0,05$. Selanjutnya peneliti ingin mengetahui bagaimana sumbangan proporsi varian dari masing masing dimensi terhadap SWB.

Koefisien Regresi Sense of Humor terhadap SWB

Pada tahapan ini, peneliti melihat pengaruh dari variabel bebas yakni sense of humor terhadap SWB, dengan perolehan hasil sebagai berikut:

Tabel 5 Hasil Uji Hipotesis Koefisien Regresi

\begin{tabular}{lcccr}
\hline \multirow{2}{*}{ Variabel } & \multicolumn{4}{c}{ Standardized Coefficients } \\
\cline { 2 - 5 } & Beta & t & Sig. \\
\hline Sense of Humor & .232 & 4.723 & .000 \\
\hline
\end{tabular}

Berdasarkan table 5, diketahui bahwasanya sense of humor secara signifikan mempengaruhi SWB, dimana nilai signifikansi sebesar $0,000<0,05$, dan memiliki arah korelasi yang positif. Selajutnya peneliti ingin mengatahui bagaimana sumbangan proporsi varian sense of humor terhadap SWB, berikut disajikan dalam tabel 5 .

Berdasarkan data pada tabel 5, diketahui sense of humor memberi sumbangan sebesar $5.4 \%$ terhadapSWB, sumbangan tersebut signifikan dengan $f$ change 22,305 
dan signifikansi $f$ change 0,000 (sig. $f$ change $<0,05)$.

\section{Pembahasan}

Hasil analisis menemukan bahwa terdapat hubungan yang signifikan antara tipe kepribadian big five dan sense of humor dengan SWB pada mahasiswa UIN Suska Riau. Kekuatan hubungan ini ditunjukkan oleh nilai $R$ Square $=0,106 ; P=0,000(p<0,05)$ dan $\mathrm{F}=23,104$. Ini berarti secara bersamasama tipe kepribadian big five dan sense of humor mempengaruhi SWB pada mahasiswa sebesar $10,6 \%$.

Hasil penelitian mendukung penelitian tentang subjective well-being yang dilakukan oleh Schimmack, Oishi, Radhakrishan, Dzokoto dan Ahadi (2002) yaitu kepribadian memiliki pengaruh yang signifikan terhadap kepuasan hidup (life satisfaction) yang merupakan dimensi dari SWB. Namun masing masing dimensi memiliki pengaruh yang berbeda terhadap SWB. Feist, Bodner, Jacobs, Miles dan Tan (dalam Deneve dan Cooper, 1998) juga menemukan bahwa tipe kepribadian big five memiliki pengaruh yang signifikan terhadap SWB.

Selain itu hasil penelitian ini menemukan bahwa dimensi conscientiousness secara positif mempengaruhi SWB, ditunjukkan dengan nilai koefisien regresi sebesar 0,293 dengan sig $<0,05$. Begitu juga dilihat dari proporsi varian dimensi conscientiousness sebesar $8,6 \%$, hal ini berarti dimensi conscientiousness dapat menjelaskan SWB sebesar $8,6 \%$.

Hasil penelitian ini mendukung hasil penelitian sebelumnya yang dilakukan oleh DeNeve dan Cooper (1998), yang menemukan bahwa dimensi kepribadian conscientiousness memiliki hubungan yang positif dengan pengukuran SWB. Hubungan yang positif antara conscientiousness dengan SWB. juga ditunjukkan hasil penelitian McCrae dan Costa (dalam Gutierrez, Jimenez, Hernandez dan Puente, 2005). Artinya semakin mahasiswa mengarah pada tipe kepribadian conscientiousness, maka semakin tinggi SWB-nya. Conscientiousness mendeskripsikan kontrol terhadap lingkungan sosial, berpikir sebelum bertindak, menunda kepuasan, mengikuti peraturan dan norma, terencana,terorganisir, dan memprioritaskan tugas (Friedman dan Schustack, 2006;)

Berdasarkan hasil penelitian, mahasiswa yang memiliki dimensi kepribadian conscientiousness yang tinggi memiliki kemampuan dalam mengatur, menetapkan dan menggolongkan berbagai hal yang dipandang baik terhadap diri mahasiswa, kemampuan ini membuat mahasiswa dapat menghargai suatu hal. Ketika mahasiswa memiliki sifat menghargai maka akan tercipta suatu kedisiplinan dalam kehidupan mahasiswa. Disiplin membuat mahasiswa taat dan patuh terhadap suatu norma atau nilai-nilai yang terkandung dalam suatu lingkungan sosial. Sehingga mahasiswa mampu dalam hal mengontrol tingkah laku terhadap lingkungan sosial yang ada di sekitar mahasiswa. Sejalan dengan teori yang dikemukakan oleh Diener dan Suh (2000), mengatakan kemampuan mengontrol lingkungan sosial secara positif merupakan hal yang diperlukan bagi mahasiswa untuk mendapatkan tingkat komponen kognitif yang diharapkan dalam mencapai SWB.

Sedangkan keempat tipe kepribadian tidak memiliki hubungan yang signifikan terhadap SWB. Dimensi extraversion memiliki nilai koefisien regresi sebesar 0,051 dengan sig $>0,05$, yang berarti bahwa dimensi kepribadian extraversion tidak secara signifikan mempengaruhi subjective well-being. Extraversion menilai kuantitas dan intensitas interaksi interpersonal, level aktivitas, kebutuhan untuk didukung, kemampuan untuk berbahagia dan menikmati hidup (Costa dan McCrae, 1992; dalam Pervin dan John, 2012). Kategori extraversion dalam penelitian ini berada pada dalam kategorisasi sedang, artinya mahasiswa dapat bersosialisasi dengan baik dan aktif, berorientasi pada orang, namun dibalik itu seorang mahasiswa membutuhkan dukungan dan stimulasi dari timbal balik interaksi interpersonal yang dilakukannya. 
Hasil penelitian ini juga sesuai dengan temuan penelitian yang telah dilakukan oleh Gutierrez, dkk (2005) bahwa agreeableness merupakan prediktor SWB yang tidak signifikan. Dimensikepribadian agreeableness dalam penelitian ini memiliki nilai koefisien sebesar 0,022 dengan sig >0,05, yang berarti bahwa dimensi kepribadian agreeableness tidak secara signifikan mempengaruhi SWB. Agreeableness menilai kualitas orientasi interpersonal seseorang sepanjang kontinum mulai dari lemah lembut sampai antagonis didalam berpikir, perasaan dan tindakan (Costa dan McCrae dalam Pervin dan Jhon, 2012). Mahasiswa dengan skor agreebleaness yang tinggi maka mahasiswa tersebut cenderung mudah percaya pada orang lain, murah hati, suka menolong, mudah menerima dan baik hati.

Dimensi kepribadian neuroticsm memiliki nilai koefisien sebesar 0,042 dengan sig >0,05, yang berarti bahwa dimensi kepribadian neuroticsm tidak secara signifikan mempengaruhi subjective wellbeing. Neuroticsm mengidentifikasikan bahwa kecenderungan individu yang rentan terhadap tekanan psikologis, memiliki ideide yang tidak realistis dan mempunyai coping response yang maladaptive (Costa dan McCrae dalam Pervin dan Jhon, 2012). Ketika neuroticsm mahasiswa tinggi, ia akan mudah mengalami stress dan memiliki coping response yang maladaptive sehingga akan lebih sering merasakan afek - afek negatif dan jarang merasakan hadirnya afek positif, maka mahasiswa tersebut tidak akan mencapai tingkat SWB yang tinggi. Neuroticsm yang tinggi dapat mengakibatkan emosi negatif yang tinggi (Halama, 2005).

Dimensi kepribadian openness memiliki nilai koefisien sebesar $-0,004$ dengan sig $>0,05$, yang berarti bahwa dimensi kepribadian openness tidak secara signifikan mempengaruhi SWB. Openness menilai bagaimana individu menggali sesuatu yang baru dan tidak biasa, penghargaan terhadap pengalaman demi kepentingan individu sendiri (Costa dan McCrae dalam Pervin dan Jhon, 2012). Tingginya skor pada dimensi openness dapat mengarahkan mahasiswa tidak hanya kepada pengalaman-pengalaman baik, tapi juga pada pengalaman-pengalaman buruk, maka hal ini tidak akan berpengaruh baik pada SWB

Hasil penelitian ini juga menunjukkan terdapat hubungan positif yang signifikan antara sense of humor dengan SWB. nilai signifikansi sebesar $0,000<0,05$. Ini berarti tinggi rendahnya sense of humor pada mahasiswa berkaitan dengan SWB yang mahasiswa miliki. Hal ini sesuai dengan sumbangan efektif sense of humor dengan SWB, yaitu sebesar $5,4 \%$ yang memiliki pengertian bahwa sense of humormemberikan kontribusi sebesar $5,4 \%$ untuk mendukung SWB. Melalui hal ini dapat disimpulkan bahwa, semakin tinggi sense of humor yang dimiliki oleh mahasiswa maka semakin tinggi pula SWB yang dimilikinya dan semakin rendah sense of humor yang dimiliki maka semakin rendah SWBmahasiswa.

Mahasiswa yang memiliki sense of humor cenderung dalam keadaan yang memiliki SWB pula. Hal ini dikarenakan humor dapat meningkatkan emosi positif dalam diri mahasiswa dan menurunkan emosi negatif. Mahasiswa memaknai kehidupannya sebagai sesuatu yang positif dan dengan humor tersebut maka terciptalah suatu kepuasan dan kebahagian terkait dengan pencapaian yang dilakukan seorang mahasiswa dalam hidupnya.

Berdasarkan hasil penelitian, diketahui bahwa mayoritas mahasiswa yang menjadi subjek penelitian ini memiliki tingkat sense of humor yang berada pada kategori sedang $(70,2 \%)$. Hal ini menunjukkan bahwa mahasiswa sudah cukup baik dalam merasakan emosi positif walaupun dirinya dalam keadaan tertekan dan panik. Ini terjadi karena sense of humor yang dimiliki mahasiswa mampu untuk memodifikasi perspektif dalam situasi negatif tersebut, sehingga memperkenankan mahasiswa untuk menghindar dalam mengalami afek negatif dalam situasi tertentu. Dalam aspek kognisi, dengan tingkat kategori sense of humor yang cukup baik ini mahasiswa mampu 
mengapresiasi dan memproduksi humor melalui proses kognisi.

Sementara itu, hasil penelitian ini menemukan bahwa SWB yang dimiliki mahasiswa berada dalam kategori sedang $(49,1 \%)$. Hal ini mengartikan bahwa kebanyakan mahasiswa yang menjadi subjek dalam penelitian ini memiliki tingkat SWB yang cukup baik. Hal ini dapat diartikan bahwa dalam kehidupannya mahasiswa sudah mampu mengatasi perasaan-perasaan negatif yang dirasakan dan merasakan kebahagian dalam hidupnya walaupun belum sepenuhnya sempurna. Kondisi ini menyebabkan mahasiswa pada waktu dan kondisi tertentu merasa puas dengan kehidupan yang dijalaninya, namun pada waktu dan kondisi yang lain merasa kurang puas dengan kehidupan yang dijalaninya.

\section{Kesimpulan}

Berdasarkan hasil penelitian yang dilakukan, dapat diambil kesimpulan bahwa hipotesis dalam penelitian ini diterima yaitu terdapat hubungan signifikan antara tipe kepribadian big five dan sense of humor dengan SWB pada Mahasiswa UIN Suska Riau.. Dari hasil uji hipotesis minor yang menguji signifikansi masing-masing koefisien regresi terhadap dependent variable, diperoleh dua koefisien regresi yang signifikan yaitu tipe kepribadian big five dimensi conscientiousness dan sense of humor.

Empat tipe kepribadian big five yang tidak signifikan dari hasil uji hipotesis minor terhadap dependent variable. Masingmasing tipe kepribadian big five yang tidak signifikan ini adalah extraversion, agreeableness, neuroticsm dan openness. SWB dapat diwujudkan melalui kepribadian conscientiousness dan sense of humor.

\section{Daftar Pustaka}

Arikunto, S. (2010). Prosedur Penelitian: Suatu Pendekatan Praktik. Jakarta: Rineka Cipta.

DeNeve, K.M \& Cooper, H. (1998). The Happy

Personality: A Meta-Analysis of 137
Personality Traits and Subjective WellBeing. Psychological Buletin. 124, (2), 197-229

Diener, E, (2000). Subjective Well-Being The Science of Happiness and a Proposal for a National Index. American Psychological Association Vol. LV (1), $34-43$.

Diener, E., \& Biswas-Diener, R, (2008), Happiness: Unlocking the mysteries of psychological wealth. Malden, MA : Blackwell Publishing.

Diener, Ed. (1984). Subjcetive Well Being. Psychological Bulletin American Psychological Association, Inc., 95, (3), 542-575.

Diener, Ed. (1994). Assesing Subjective Well Being : Progress and Opportunities. Netherlands: Kluwer Academic Publisher.

Diener, Ed. (2009). The Science of WellBeing. New York : Springer Science + Bussiness Media.

Diener, Ed., Suh, E.M, Lucas, R.E., \& Heidi L. Smith, (1999) Subjective Well Being: Three Decades of Progress. Psychological Bulletin, Vol. 125,.(2,) 276-302.

Erlangga, S.W. (2012). Subjective well being pada lansia penghuni panti jompo. Jurnal Psikologi. Fakultas Psikologi Universitas Gunadarma.

Feist, J., \& Feist, G.J. (2010). Teori Kepribadian (Edisi 7 Buku 2). Jakarta: Salemba Humanika.

Forest, K.B. (1996). Gender and the Pathways to subjective well-being. Social Behavior and Personality, 24 (1), 19-34.

Gutierrez, J.L.G., Jimenez, B.M., Hernandez, E.G., \& Puente, C.P. (2005). Personality and Subjective Well-Being: Big Five Correlates and Demographic Variables. Personality and Individual Differences. 1561-1569.

Hafzah. (2014). Hubungan Sense of Humor guru dalam mengajar di kelas dengan motivasi belajar siswa di SMA Negeri 1 Sangatta Utara. E-Journal Psikologi. 2(1): 14-23.

Humaira, G.R., \& Qodariah, S. (2017). 
Hubungan sense of humor dengan subjective well-being pada comic stand up indo di kota bandung. Prosiding Psikologi, 3 (1), 24-29.

Johnson, J. (2011). Measuring Thirty Facets of The Five Factor Model with a 120-Item public domain inverntory: Development of the IPIP-NEO-120. Journal of research in Personality. 60. 1-46.

Karim, S.,(2018) Hubungan Antara Dimensi Big Five Personality Dan Religiusitas Dengan Subjective Well-Being Karyawan. https://www.researchgate.net DOI: 0.20527/ecopsy.v5i1.4883

ibran, Eliseo Chico. (2006). Personality Dimensions and Subjective Well-Being. The Spanish Journal of Psychology. 9 (1). 38-44.

Martin, R.A. (1998). The Psychology of Humor: an Integrative Approach. London: Department of Psychology University of Western Ontario London.

Martin, R.A. (2007). The Psychology of Humor: An Integrative Approach. Burlington, MA: Elsevier Academic Press.

McGee, E., \& Shevlin. M. (2009). Effect of Humor on Interpersonal Attraction and Mate Selection. The Journal of Psychology, 143, (1), 67-77.

McCrae, R.R., and O.P. John. (1992). An Introduction to The Five-Factor Model and its Applications. Journal of Personality. 60, 175-215.

Nabila, A.Z. (2011). hubungan antara sense of humor dan tipe kepribadian ekstrovert dengan subjective well-being pada karyawan dewasa madya di pt telkom distel yogyakarta. Skripsi. Program Studi Psikologi Fakultas Kedokteran Universitas Sebelas Maret.

Nelvi. (2015). Hubungan Antara Dimensi Kepribadian Big Five dengan Perilaku Makan pada Mahasiswa UIN Suska Riau di Pekanbaru Riau (Skripsi). Pekanbaru: Fakultas Psikologi Universitas Islam Negeri Sultan Syarif Kasim Riau.

Pareek, S \& Jain, M. (2012). Subjective Well-Being in Relation to Altruism and Forgiveness Among School Going
Adolescentts. Jurnal of Psychology. 2(5): 138-141.

Pervin, L.A., Cervone, D., \& John, O.P. (2012). Psikologi Kepribadian Teori dan Penelitian (Edisi Kesembilan). Jakarta: Kencana

Schimmack, Oishi, Radhakrishnan \& Dzokoto. (2002). Culture, Personality, and Subjective Well-Being: Integrating Process Models of Life Satisfaction. Journal of Personality and Social Psychology. 82. (4). 582-593.

Tairas, Mareyke M.A.W. (2008). Problema Psikologi Mahasiswa: Akibat dan Solusinya. Surabaya: Airlangga University Press.

Thorson, J.A., \& Powell, F.C. (1993). Sense of Humor and Dimensions of Personality. Journal of Clinical Psychology, 49, 6, 799-809.

Thorson, J.A., Powell, F.C., Schuller, J.S., \& Hampes, W.P. (1997). Psychological Health and Sense of Humor. Journal of Clinical Psychology, 53, (6), 605-619.

Watson, D., Clark, L.E., \& Tellegen, A. (1988). Development and Validation of Brief Measures of Positive and Negative Affect: The PANAS Scale. Journal of Personality and Social Psychology, Vol. 54 (6). 1063-1070. 